\title{
MATERNITY AND LABOUR MARKET OUTCOME: SHORT AND LONG TERM EFFECTS
}

Agar Brugiavini, Giacomo Pasini,

Elisabetta Trevisan 


\title{
13 Maternity and Labour Market Outcome: Short and Long Term Effects
}

\author{
Agar Brugiavini, Giacomo Pasini and Elisabetta Trevisan
}

\subsection{Maternity and labour market outcomes}

Retirement patterns, as well as continuity and length of work histories, are strongly influenced by the events over the life cycle. This is particularly true for women. Gender differences in work-careers and the role of women within the family usually lead to fewer pension rights and lower retirement income for women than for men. In particular, maternity is likely to be one of the major drivers of gender differences on life time economic outcomes such as labour force participation, differential productivity and wages and eventually retirement income.

The effect of motherhood on women's labour supply has been a long-standing focus of economic research seeking to explain the rise in the labour force participation of women over the past decades, together with the decline in fertility rate; it has also been the cornerstone of public policy regarding the efficient design of parental leave and benefit (Troske and Voicu, 2009). The research on this topic focuses on the effect of timing and spacing of births to explain the decrease in fertility characterizing OECD countries; a few studies look instead at the effect of timing and spacing of births on women's labour market outcome (Gustafsson, 2001). One of the main results is that timing and spacing between births matter substantially for labour market participation: women who have the first child later in life exhibit a lower probability of dropping out of the labour force and lower negative effects on wages compared to other women. Moreover, the drop-out effect induced by maternity increases with the number of children. As for the longterm effects of maternity, very little is known and the evidence is very scanty.

The aim of this paper is to fill this gap by analyzing the long term effects of childbearing, i.e. the effect of motherhood on pension income at retirement, given the labour market participation of women at childbirth. Since labour market attachment is higher for younger generations, it is relevant for policy makers to look at the behaviour of women who want to work excluding those who plan a "familylife" (see also Lyberaki et al. in chapter 12 of this volume). SHARELIFE is particularly suitable for this analysis since it contains complete life time histories, including all the employment and maternity episodes experienced by European women currently aged 50 and over. Moreover, details on maternity leave provisions and other institutional features of the SHARE countries are collected and provided together with the survey data. These institutional features allow us to investigate if and how the presence of maternity benefits affects the labour market 
participation decisions of women after childbirth and, consequently, the impact of pension income at retirement.

\subsection{Maternity leave across Europe}

The existence of maternity leave provisions at the time of motherhood is likely to influence the labour market participation of women and pension income at retirement. The main characteristics of maternity leave are the duration and the amount of the benefit, the latter usually expressed as percentage of the wage. Table 13.1 summarizes these variables for each country.

Table 13.1: Maternity leave provisions across Europe

\begin{tabular}{lrrr}
\hline Country & $\begin{array}{r}\text { Year of } \\
\text { introduction }\end{array}$ & $\begin{array}{r}\text { Duration } \\
\text { (weeks) }\end{array}$ & $\begin{array}{r}\text { Benefit } \\
\text { (\%) }\end{array}$ \\
\hline Sweden & 1970 & $26-64$ & $48-90$ \\
Denmark & 1970 & $14-30$ & $88-100$ \\
Germany & 1970 & 14 & 100 \\
Netherlands & 1970 & $12-16$ & 100 \\
Belgium & 1970 & $14-15$ & $60-77$ \\
France & 1970 & $14-16$ & $50-100$ \\
Switzerland & 1970 & $10-16$ & 100 \\
Austria & 1950 & $12-16$ & 100 \\
Italy & 1970 & $17-21,5$ & 80 \\
Spain & 1970 & $12-16$ & $75-100$ \\
Greece & 1970 & $12-16$ & 50 \\
Poland & 1974 & 16 & 100 \\
Czech Republic & 1961 & 28 & 69 \\
\hline
\end{tabular}

Note: Benefit is expressed as a percentage of wages in the manufacturing sector. Maternity leave provisions information are not available for East Germany separately from West Germany. The two numbers for the duration and the benefit columns indicate respectively the lowest and the highest number of weeks and benefit level fixed by law during the years.

There is variability between countries in terms of maternity "protection". In all European countries, with the exception of Austria and Czech Republic, maternity leave provisions have been introduced in 1970 and have gone through several changes. Sweden, Denmark and Italy are characterized by a longer duration of the maternity leave with respect to other countries. However, all countries show a trend towards the increase of duration of maternity benefits in the last decades. Countries with shorter durations compensate with generous benefits, varying be- 
tween $80 \%$ and $100 \%$ of the wage. Greece, Belgium and the Czech Republic are exceptions.

\subsection{Short term effects}

One important economic effect of childbearing is a change in labour market participation of women after childbirth. Hence we look at the subsample of women who were working at the time of motherhood (for any child), which is clearly a selected group of the population. Figure 13.1 shows that the labour market participation rate of women at the time of childbirth is indeed very heterogeneous across countries.

Figure 13.1: Fraction of women working at the time of childbearing by country

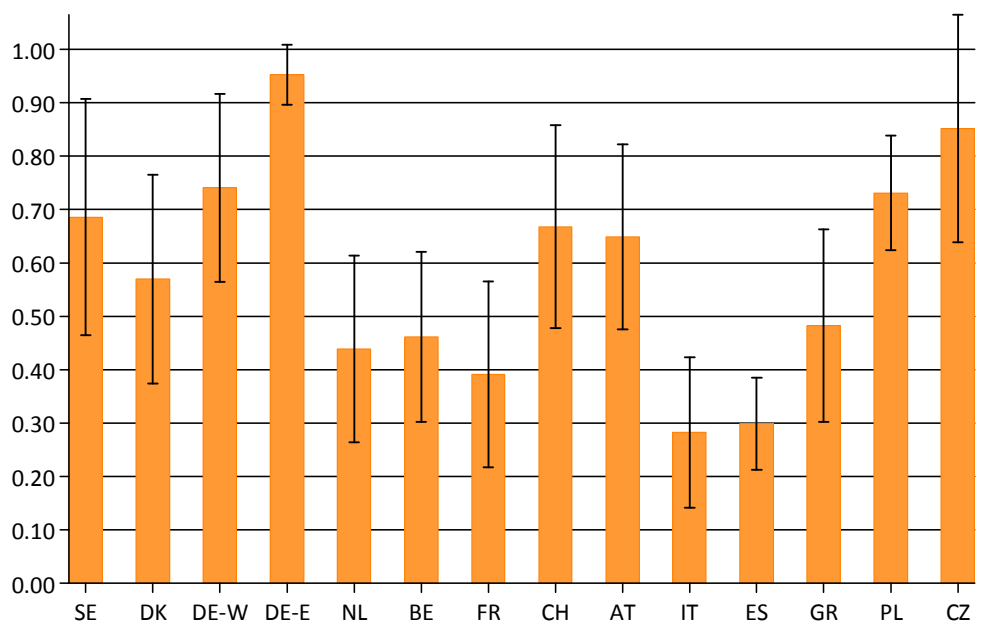

In some countries, such as Italy and Spain, the fraction of women working at the time of childbirth is very low (about 30\%). In most of the other countries the labour market participation rate of women is above $50 \%$, with peaks of $90 \%$ for Czech Republic and East Germany.

In SHARELIFE, for each maternity episode, it is asked whether the respondent continued working without interruption, stopped temporarily her job (maternity leave) or left the labour market and never worked again. The average drop-out rate from the labour market at childbearing by country and number of children is shown in Table 13.2. The table shows that the choice of whether to continue working for women, in case of motherhood, is influenced by the number of children. 
We observe an increasing frequency of exits from the labour market as the number of children increases for almost all countries. Table 13.2 shows also a high variability between countries, which is likely to be related to country-specific cultural differences as well as to differences in maternity leave provisions.

Table 13.2: $\quad$ Drop-out rate at childbearing by country and number of children

\begin{tabular}{lrrrr}
\hline Country & One child & Two children & Three children & Four children \\
\hline Sweden & 0.06 & 0.06 & 0.07 & 0.10 \\
Denmark & 0.22 & 0.12 & 0.19 & 0.32 \\
West Germany & 0.42 & 0.24 & 0.29 & 0.38 \\
East Germany & 0.35 & 0.28 & 0.48 & 0.24 \\
Netherlands & $0: 26$ & 0.12 & 0.17 & 0.06 \\
Belgium & 0.51 & 0.57 & 0.50 & 0.49 \\
France & 0.48 & 0.51 & 0.54 & 0.49 \\
Switzerland & 0.34 & 0.23 & 0.28 & 0.33 \\
Austria & 0.22 & 0.25 & 0.27 & 0.35 \\
Italy & 0.39 & 0.43 & 0.41 & 0.45 \\
Spain & 0.51 & 0.33 & 0.44 & 0.27 \\
Greece & 0.22 & 0.26 & 0.15 & 0.30 \\
Poland & 0.31 & 0.31 & 0.42 & 0.57 \\
Czech Republic & 0.04 & 0.06 & 0.11 & 0.09 \\
\hline
\end{tabular}

Note: The drop-out rate is calculated as the ratio between the number of women who were working at the time of childbirth and never worked again and the total number of women who were working at the time of childbirth (by number of children).

Figure 13.2 shows country averages of labour market consequences of childbearing, conditional on the number of children and on the existence of maternity benefit at the time of childbirth.

Figure 13.2: Labour market attachment after childbearing conditional on the presence of maternity benefits (women with two children) 

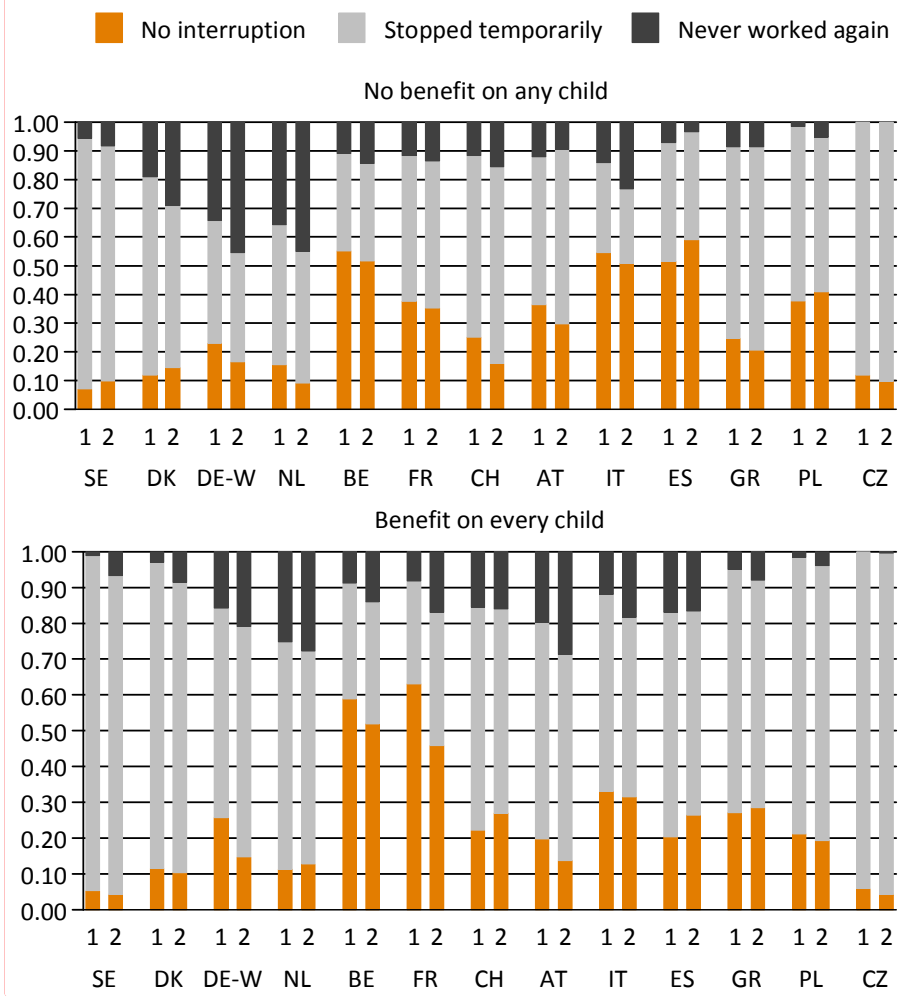

Note: In the graphs women with 2 children are considered, for each child the labour market outcome is shown. Czech Republic and Austria are not present in the left panel (without maternity benefit) because all women having two children are covered by maternity leave provisions.

Comparing labour force participation in the absence (left panel) and presence (right panel) of maternity benefits at the birth of the oldest child, a high variability between countries emerges. The puzzling result is that in some countries the existence of maternity benefits seems to increase the probability of dropping out of the labour market. It should be noted that, in this particular case, the sample size in some countries may be small as we restrict the attention to women with two children.

The introduction of maternity leave provisions aimed at mitigating the income drop of mothers and at providing incentives to stay in the labour market. The descriptive evidence is mixed: the overall effect of these policies on labour market participation depends on the cohort of the mother, as well as on the number of children at the moment of childbearing. Even after controlling for these characteristics we obtain a large cross-country heterogeneity in labour force participation. This seems to indicate that the effectiveness of public policies for maternity pro- 
tection does not depend solely on length and generosity of those benefits, but also on individual preferences, cultural traits, as well as other transfers in money and in kind at childbearing, such as public day-care provisions.

\subsection{Long term effect}

The number and timing of children could also have long term effects. In particular, pension provisions are typically related to working life history: the number and length of employment interruptions of mothers could affect their social security (pension) income at retirement (Boeri and Brugiavini, 2009).

In order to explore such a long term effect, we first look at the relation between the number of children, the labour market participation decision at childbirth and the social security (pension) replacement rate. We define the replacement rate as the ratio of the first pension benefits received after retirement and the last wage received. Figure 13.3 shows the relationship between the replacement rate and the number of children at the aggregate level.

What emerges is a relatively high variability in fertility rates across countries, compared with the dispersion of actual replacement rates. As a result, there is a small negative correlation between the two, which is not statistically significant.

Figure 13.3: Average pension replacement rate by country and number of children

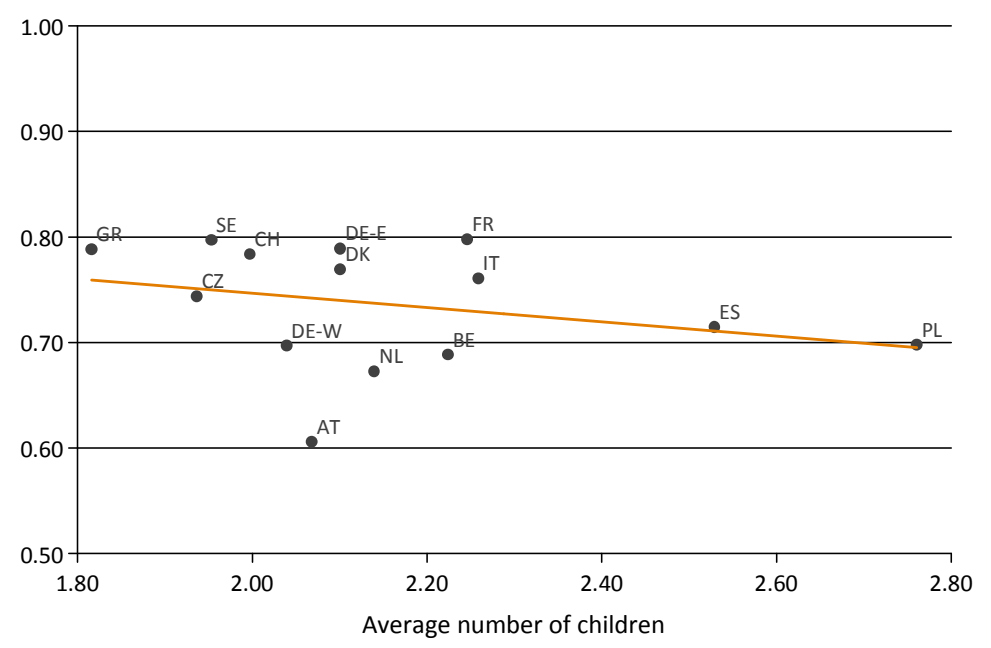

The aim of this analysis is to identify the effect of the existence and generosity of maternity leave programs on the pension income at retirement. Thus, we focus on 
those women who had at least one child and who were working at the time of the first childbirth. More specifically, starting from a sample of 15,544 women, 15,523 have at least one child and among them 8,963 were working at the time of first childbirth. About $44 \%$ of these women $(3,986)$ are retired, while the majority of them is still working, disabled, unemployed or out of the labour force for other reason.

We now focus on the effect of maternity leave provisions on pension income at retirement at individual level. This effect is captured by three variables: a dummy variable accounting for the existence of maternity leave provisions at the time of first childbirth, a variable describing the benefit received during maternity leave as a percentage of the wage and a variable indicating the length of maternity leave in weeks. If maternity leave provisions are introduced after the first motherhood, women may change their fertility decisions according to these policy decisions. Modelling the interplay between individual fertility choices and the timing of the introduction of maternity leave benefits goes beyond the scope of this paper, thus we consider the existence and the characteristics of maternity leave provisions only at the time of first childbirth. Moreover, we include simultaneously country dummies among the regressors besides maternity leave indicators: while country dummies capture country-specific effects, the maternity leave indicators capture variations both across countries and over time.

Table 13.3: Regression analysis of the social security pension income (log)

\begin{tabular}{|c|c|c|c|c|}
\hline Variables & (1) & (2) & (3) & (4) \\
\hline \multicolumn{5}{|l|}{$\begin{array}{l}\text { Maternity leave } \\
\text { provision: }\end{array}$} \\
\hline \multirow[t]{2}{*}{ Existence } & $0.204 * * *$ & & & $0.794 * * *$ \\
\hline & (0.039) & & & $(0.217)$ \\
\hline \multirow[t]{2}{*}{$\begin{array}{l}\text { Maternity benefit } \\
\text { replacement rate }\end{array}$} & & $-0.002 * * *$ & & $-0.006 * *$ \\
\hline & & $(0.000)$ & & $(0.002)$ \\
\hline \multirow[t]{2}{*}{ Length } & & & $-0.010 * * *$ & -0.005 \\
\hline & & & $(0.003)$ & $(0.005)$ \\
\hline \multirow[t]{2}{*}{ Stopped temporarily } & $-0.094^{* *}$ & $-0.095^{* *}$ & $-0.093 * *$ & $-0.091 * *$ \\
\hline & (0.039) & (0.039) & (0.039) & (0.039) \\
\hline \multirow[t]{2}{*}{ Drop-out } & $-0.400 * * *$ & $-0.401 * * *$ & $-0.409 * * *$ & $-0.402 * * *$ \\
\hline & $(0.067)$ & $(0.067)$ & $(0.067)$ & $(0.067)$ \\
\hline
\end{tabular}




\begin{tabular}{lcccc}
\hline Number of children & $-0.033^{* *}$ & $-0.033^{* *}$ & $-0.038^{* * *}$ & $-0.035^{* *}$ \\
& $(0.019)$ & $(0.014)$ & $(0.013)$ & $(0.014)$ \\
& & & \\
& & & & $F(3,2744)$ \\
& & & $=11.90$ \\
F-test & & & Prob $>\mathrm{F}$ \\
& 3,986 & 3,986 & 3,986 & $=0.0000$ \\
N. Obs. & & & 3,986 \\
\hline
\end{tabular}

Note: $*, * *, * *$ stand for $90 \%, 95 \%$ and $99 \%$ level of significance respectively. The dependent variable is the log of first pension benefit at retirement, Existence is a dummy variable taking value 1 if there were maternity leave provisions at the time of first childbirth and 0 otherwise; Maternity benefit replacement rate is the institutional maternity benefit level (as \% of the wage) at the time of first childbirth; Length is the institutional length of maternity leave at the time of first childbirth. In all models we control for years of education, job characteristics, and country dummies. The amounts of the benefits at retirement have been corrected for within countries differences in currencies and have been converted in Euro (exchange rate 2001).

In Table 13.3 we present the results of the regression analysis for the log of social security pension income when controlling, in turn, for the existence of maternity leave (column 1), the benefit level (column 2) and the length of maternity leave (column 3). The length and generosity of maternity leave provisions have a negative and significant effect on pension income at retirement. Long spells due to maternity leaves might induce women to stay longer out of labour force and longer non-employment spells could have worsened the labour market opportunities after re-entering the job market, thus reducing wages and benefits compared to women with shorter interruption (this is in line with Troske and Voicu, 2009). Considering the three variables together (column 4 ), the existence of maternity benefit has a positive and significant effect, while the level of the benefit has a negative and significant effect (the three variables are jointly significant). Moreover, the pension income at retirement is lower both for women leaving temporarily their job and for women dropping out from labour market compared to women without interruptions in their careers. There are no major differences across countries.

Hence our investigation suggests that, by and large, time spent out of the labour market and generous maternity benefits could have a negative effect on the pension income at retirement.

However, the fertility decision of women is likely to be endogenous. In order to deal with the simultaneity issue, we estimate the effect of maternity leave provision on the pension income at retirement using an instrumental variable approach, where the number of biological brothers and sisters of the mother at the age of ten is used as instrument for the number of children. The idea is that the fertility history in the household in which the woman grew, which is reflected in the number of brothers and sisters, influences her fertility decision, but it is not related to her labour market participation. More precisely, the number of brothers and sisters at the age of 10 could influence the labour market participation of women at very 
young ages (women with more siblings might be pushed to go to work earlier), but it is unlikely to have any direct effect on labour market participation choices later in life. In our analysis we consider women who were working at the time of childbearing and we look at the labour market participation after childbirth, thus, on the basis of the above arguments, we can assume that our instrument is still valid. Table 13.4 shows the estimation results.

As in Table 13.3, the results of Table 13.4 show that women who left their job temporarily and women dropping out from the labour market after childbirth have a significantly lower pension income at retirement than women who did not leave their jobs. There are no significant differences across countries.

The IV estimates are very much in line with the ones deriving from the OLS regression. More specifically Table 4 shows (columns (1) to (3)) that, when the variables related to the maternity leave provisions are included separately, the existence of maternity leave provisions has a positive and significant effect, while length and generosity of maternity benefit have a (negative) significant effect on the social security pension benefit. When the "maternity variables" are included together (column 4), while the existence of maternity leave provisions has a strong and positive effect, the level of the maternity benefit reduces the social security pension income at retirement and the length of the benefits is not statistically significant.

Table 13.4: Instrumental variable regression of the pension income (log)

\begin{tabular}{|c|c|c|c|c|c|}
\hline Variables & (1) & (2) & (3) & (4) & \\
\hline $\begin{array}{l}\text { Maternity leave } \\
\text { provision: }\end{array}$ & & & & & \\
\hline Existence & $\begin{array}{l}0.183^{* * *} \\
(0.060)\end{array}$ & & & $\begin{array}{l}0.822 \\
(0.231)\end{array}$ & $* * *$ \\
\hline $\begin{array}{l}\text { Maternity } \\
\text { benefit re- } \\
\text { placement rate }\end{array}$ & & $\begin{array}{l}-0.002^{* *} \\
(0.000)\end{array}$ & & $\begin{array}{l}-0.007 \\
(0.002)\end{array}$ & $* *$ \\
\hline Length & & & $\begin{array}{l}-0.009 * * * \\
(0.004)\end{array}$ & $\begin{array}{l}-0.005 \\
(0.005)\end{array}$ & \\
\hline $\begin{array}{l}\text { Stopped tem- } \\
\text { porarily }\end{array}$ & $\begin{array}{l}-0.102^{* *} \\
(0.044)\end{array}$ & $\begin{array}{l}-0.103^{* *} \\
(0.043)\end{array}$ & $\begin{array}{l}-0.101^{* *} \\
(0.044)\end{array}$ & $\begin{array}{l}-0.098 \\
(0.043)\end{array}$ & $* *$ \\
\hline Drop-out & $\begin{array}{l}-0.392^{* * *} \\
(0.069)\end{array}$ & $\begin{array}{l}-0.393 * * * \\
-(0.069)\end{array}$ & $\begin{array}{l}-0.402^{* * *} \\
-(0.069)\end{array}$ & $\begin{array}{l}-0.394 \\
(0.069)\end{array}$ & $* * *$ \\
\hline
\end{tabular}




\begin{tabular}{lrrrl}
\hline $\begin{array}{l}\text { Number of chil- } \\
\text { dren }\end{array}$ & & & \\
& -0.078 & -0.079 & -0.080 & -0.083 \\
& $(0.107)$ & $(0.107)$ & $(0.107)$ & $(0.107)$ \\
& & & \\
F-test & & $F(3,2740)$ \\
& & & $=8.64$ \\
& & $P>F$ \\
N. Obs. & 3,977 & 3,977 & 3,977 & $=0.000$ \\
\hline
\end{tabular}

Note: $*, * *, * * *$ indicate $90 \%, 95 \%$ and $99 \%$ level of significance respectively. In the regressions the dependent variable is the log of first pension benefit at retirement, Existence is a dummy variable taking value 1 if there were maternity leave provisions at the time of first childbirth and 0 otherwise; Maternity benefit replacement rate is the institutional maternity benefit level (as \% of the wage) at the time of first childbirth; Length is the institutional length of maternity leave at the time of first childbirth. In all models we control for a set of variables, such as years of education, job characteristics, country dummies. The amounts of the benefits at retirement have been corrected for within countries differences in currencies and have been converted in Euro (exchange rate 2001).

We can conclude that the existence of maternity benefits improved long term economic conditions for mothers, but the generosity (replacement rate of the maternity benefit) of the maternity benefit had a negative effect on pension income at retirement.

\subsection{Conclusion}

The number and timing of children are likely to affect labour market participation of women (what we called short time effects) and, through the induced discontinuity of work careers, they also affect retirement income.

In this paper we first describe the labour market attachment of women at childbirth, then we analyze the long term effect of childbearing, i.e., the pension income at retirement, focusing on the effect of the existence and characteristics of the maternity leave arrangements provided in each country.

The main results in terms of "short-term" and "long-term" economic outcomes can be summarised as follows:

- The "exit from the labour market" effect due to childbearing is increasing in the number of children.

- There is a high variability in the pattern of participation across countries related to differences in maternity leave provisions; however, institutional features are not the only determinants of the interaction between fertility and labour force participation. 
- The existence of maternity leave provisions has a positive effect on the social security pension benefit at retirement.

- The generosity of maternity benefits reduces the social security pension income.

- Results hold even after controlling for the endogeneity of fertility decisions.

Overall, both for short-term labour market outcomes and for the social security pension income, the introduction of maternity benefits, aimed at mitigating the reduction in income of mothers and at providing incentives not to leave the labour market, did lead to an improvement in the economic conditions of mothers, but the characteristics of the maternity leave provisions such as the level of the benefit may reduces their beneficial effect.

\section{References}

Boeri, T. and Brugiavini, A. (2009). Pension Reforms and Women Retirement Plans. Journal of Population Ageing, Vol. 1, pp. 7-30.

Gustafsson, S. (2001). Optimal Age at Motherhood. Theoretical and Empirical Considerations on Postponement of Maternity in Europe. Journal of Political Economy, Vol. 85, pp. 225-217.

Troske, K.R. and Voicu, A. (2009). The Effect of the Timing and Spacing of Births on the Level of Labor Market Involvement of Married Women, IZA Discussion Paper, N. 4417. 